\title{
WOMEN RESISTANCE TOWARD DISCRIMINATIONS: A MODERN LITERARY WORK ANALYSIS ON FEMINISM REVIEW IN BEKISAR MERAH
}

\author{
Mujiono and Moh. Zalhairi \\ moejie_nova73@yahoo.com; brong_sumpret@yahoo.com \\ English Education Department, Language and Literature Faculty, \\ University of Kanjuruhan Malang, Indonesia
}

\begin{abstract}
This study was conducted to discover the discriminations against women in the Bekisar Merah novel and how they formulate resistance to those discriminations. To address the above objective, this study used descriptive qualitative research design with a feminism approach. Source of the data in this study was the second edition of Bekisar Merah novel written by Ahmad Tohari. The data included were words, phrases, sentences, and paragraphs on Bekisar Merah which portray women's discrimination toward Lasi, the women figure in the novel, and power types formulated by her who resisted the discrimination. To analyze the data, content analysis was applied. Triangulation was used to ensure the trustworthiness of the data. The result of the study showed eight forms of discriminations and three resistances. The discriminations were domestic abuse, molestation, gender harassment, seduction behavior, imposition, coercion, bribery, and subordination. The resistances were physically, mentally, and verbally.
\end{abstract}

Key words: resistance, feminism, and discrimination

Abstrak: Penelitian ini dilakukan untuk mendiskripsikan diskriminasi terhadap perempuan pada novel Bekisar Merah dan mendiskripsikan bagaimana mereka merumuskan perlawanan terhadap diskriminasi tersebut. Untuk mencapai tujuan di atas, penelitian ini menggunakan rancangan penelitian diskriptif kualitatif dan pendekatan feminisme. Sumber data dalam penelitianini adalah novel Bekisar Merah edisi kedua yang ditulis oleh Ahmad Tohari. Datanya berupa kata, frase, 
kalimat dan paragraf pada novel Bekisar Merah yang menggambarkan diskriminasi terhadap Lasi sebagai figur perempua npada novel tersebut dan bentuk kekuasaan yang dirumuskan oleh dia yang menolak diskriminasi. Analisis isi dilakukan untuk menganalisis data. Triangulasi digunakan untuk mendapatkan keabsahan data. Hasil penelitian menunjukkan delapan bentuk diskriminasi dan tiga resistansi perempuan. Diskriminasi yang berupa kekerasan dalam rumah tangga, pemaksaan, penganiayaan, pelecehan, perilaku rayuan, paksaan, penyuapan, dan perendahan martabat wanita. Resistensi wanita berupa fisik, mental, dan lisan.

Kata- kunci: resistensi, feminism, dan diskriminasi

\section{INTRODUCTION}

Literary work is the way to extend the idea of the writer about the dynamic activities of human life. Literary work is a human creation which is reflected from real life (Luken, 2003). The idea of writing a literary work starts by perceiving human life which led to restlessness. The restlessness usually brings a writer to think and create a new world in form of literary works. In Windiyati's opinion literary work has its own existence which shows a reality using a beautiful language (2008).

In line with the above statements, literary work is, therefore, not in social alienation, but it represents a phenomenon that occurred in a society. Many problems usually emerge in human life that it becomes interesting to be represented by literary works. One of them is what is known as gender bias. It is the understanding of men and women's different roles based on sex. Women are isolated in domestic works while men are in some productive ones. This understanding finally creates what we know as patriarchy culture which puts man as a superior being and brings women not only to be subordinated but also to be treated in incorrect ways, such as violence.

One of the novelists who present this issue in his work is Ahmad Tohari, through his novel, Bekisar Merah (2013). The novel portrays the practice of patriarchy culture which legitimizes man's domination over women. It also presents violence against women which are practiced in different ways. Lasi, the women figure in the novel, got unfair treatments since she was young until she became the wife of Mr. Bambung, a millioner and authority holder in her country. 
Underlying the above statements, studies in feminism have been investigated by a great number of scholars from a wide range of disciplines. Windiyati (2008) revealed that there is (1) an injustice against women manifested in the class system in the society of Bali, which became the setting of the novel, (2) various forms of gender injustice or inequity that was reflected in the family, and (3) the study was about women radicalism. Radicalism was shown by the main character in the novel that is trying to obtain equality by getting married with a man from a Brahman caste. Unfortunately radicalism tends to benefit the main character only. In fact, this benefit to the main character happened during the existing oppressive system.

Other scholars such as Ambarwati, (2009), and Kuncoro (2010) have investigated feminism from the point of view where feminism was associated with feminism perspectives. The findings revealed that women exist as independent human beings, irrespective of all forms of gender oppression and are able to demonstrate status and dignity as human beings. Existence was realized in the form of freedom to choose and decide what they thought was right, without their thoughts being determined by men. Meanwhile, Kurnia et. al (2013) had studied about feminism in the novel of Secuil Hati Wanita di Teluk Eden written by Vanni Chrisma. Kurnia et. al's analysis finds that (1) gender inequity experienced by the main character is manifested in the form of stereotypes, (2) violence experienced was in the form of domestic: either as physical or emotional, and (3) the struggle of women drawn from the results of these studies was limited only to the awareness and freedom of speech. That is why modern literary work analysis on feminism review, which explore ideas of the writer and about the dynamics of human life specifically on women resistance toward discriminations is an interesting topic to conduct.

\section{LITERATURE REVIEW}

\section{A. Gender as perspectives}

Gender is not something people are born with, and not something owned, but something that is done or performed (West \& Zimmerman, 1987; Butler, 1990). Rudman and Glick (2008) argue that gender relations involve intimate heterosexual interdependence, which often shows the genuine feelings of love and affection between the sexes. In its lexicon meaning, gender is represents the genitalia of man and women. According to Sugihastuti and Sastriyani (2007) gender is categorized into two specific definitions. The first 
relates to what is understood as genital organs like understood by Rudman and Glick above. The second, however, is the social construction of gender. The social construction defines women as weak, having soft characteristic, being fussy, participating motherhood, and are infamously emotional, while men are strong and rationale. Meanwhile, Money (1988) has introduced the terminological distinction of the genital organ as biological sex and the social construction as gender.

Oakley, as cited by Freedman (2001), argues that sex is a word that refers to the biological differences between male and female. It is the visible difference in genitalia, the related difference in procreative function. Gender, however, is a matter of culture. It refers to the social classification into masculine and feminine but gender is not only about the genital differences between man and women revealed by God. With regards to two previous statements, Fakih (2012) distinguishes between sex and gender As follows. Sex is something which is permanent while gender is termed after behavioral differences between men and women and is socially constructed. Related to the above arguments, Money (1998) puts a deep difference between gender as a role of human and sex as part of our body. He says that gender as role is a set of societal norms which dictates what sort of behavior is commonly acceptable for a person based on their actual experiences.

Another scholar, Umar (2005) gives a specific explanation to understand the concept of both terms. He divides the concept of gender into four parts. They are gender attribute, gender identity, gender assignment, and gender role. Gender attribute is what have been explained above as genital organs while gender identity is a set of symbols which is associated with men and women based on their gender attributes. Gender assignment and gender role in Umar's explanation are similar. Both are socially constructed and indicates what men and women must do. Society categorizes what they must do based on the genital limitation of their body. Gender is a set of behavior that is learned and performed. It is something we do, not what we are, and it can change from culture to culture and even in individual attitudes over the course of a lifetime.

\section{B. Gender inequalities}

According to Fakih (2012), gender can be manifested in form of (1) women marginalization, (2) women subordination, (3) creating a stereotype to women, and (4) women violence and work burden. The first, in women marginalization, gender inequality has a great impact especially on women and 
poverty. In poverty stricken countries, it is more likely that men have more opportunities to have an income and have more political and social rights than women. Some strategic positions in the industry, politic institution, office, and organization put women subordinate to men. In career, women usually perform only as a secretary or treasurer, thus, women most likely experience more poverty than men (Fakih, 2012).

Based on Sultana (2010), the term women's subordination refers to the inferior position of women, their lack of access to resources and decision making. Women's subordination means the inferior position of women to men. The feeling of powerlessness, discrimination and experience of limited self-esteem and self-confidence jointly contribute to the subordination of women. In support of this, Herlambang (2013) argues that subordination is the cultural violence faced by women. It can be legitimated from ideology, language, religion, art, and knowledge. The reality which is commonly found in the society shows that religion has a great position in legitimating the gender inequalities. Religion interprets gender as something given and should be kept for it is God's rule. The effect of religious interpretation makes the society keep the violence expressive without feeling guilty. It is more ironic when women do not think they become the victim of the subordination. Women see what is done by men to them, in the form of domination, as something normal.

The third is women stereotype. This can be seen when the women beautify themselves. When there is a rape, the society most likely blames the women for they are thought as always inviting the man to do so. This is one of the examples which commonly happens and believd in a partriarchial society.

Fourth, violence is the common implication of gender bias. It is an assault to women's physical body or their phycology. One of the causes of violence is the gender bias of men who believe that they have more power than women which make them feel superior and think of women as not brave enough to fight back. Fakih (2012) states that it is because of power which is not balanced between men and women in society that this occurrence happens.

Further, Fakih, (2012) explains that the gender inequalities explained above can be classified into two broad classes which are physical and nonphysical violence. Gender inequalities like marginalization, women poverty, subordination, violence, stereotype, and work burden are manifested in many social systems. It can be in the state institution, local and world organizations 
such as United Nation (UN), state policy, and constitutions. However, the gender inequalities are also happening in public space, families, educational settings, religious settings, and many other settings (Jones, 2010; Fakih, 2012).

\section{The notion of feminism}

Gay (2012), states that the term of feminism has become misconstrued and negatively associated in the twenty-first century. Further, he explains that feminism is a movement whose primary purpose is to achieve quality in all realms between men and women. Freedman (2001) explains that feminism concerns themselves with women's inferior position in society and with discrimination encountered by women because of their sex. According to Bhasin and Khan (1995), feminism is an awareness of women who are under man's domination in many aspects and have an established set of actions to resist it. Gender inequality is the foundation of feminism movement. They believe that it is constructed time by time and from generation to generation culturally, so, the movement created is a form of struggle to get back the rights of women.

\section{Gender reform feminisms}

The term of feminism began from the gender reform of western feminism because feminism, the reaction of women discrimination, is its successor. According to Freedman (2001), gender reform feminism is categorized into three series of waves. Each wave dealt with different aspects of the same feminist issues. The first wave comprised women's suffrage movements of late-nineteenth-century and early-twentieth-century feminist movements that were concerned with gaining equal rights for women. Its focus was on the promotion of equal contract, marriage, parenting, and property rights for women. By the end of the nineteenth century, activism focused primarily on gaining political power, particularly the right of women's suffrage, although some feminists were active in campaigning for women's sexual, reproductive, and economic rights as well. The second wave was associated with the ideas and actions of the women's liberation movement beginning in the 1960s. The second wave campaigned for legal and social equality for women.

The third wave according to Krolokke (2005) was a continuation of, and a reaction to, the perceived failures of second-wave feminism. In the early 1990s in the USA, third-wave feminism began as a response to perceived failures of the second wave and to the backlash against initiatives and 
movements created by the second wave (Krolokke (2005). Third-wave feminism distinguished itself from the second wave around issues of sexuality, challenging female heterosexuality and celebrating sexuality as a means of female empowerment (Cameron, 2010). Further, he explains that third-wave feminism also seeks to challenge or avoid what it deems the second wave's essentialist definitions of femininity, which they argue, over-emphasize the experiences of upper middle-class white women. By the 20th century covertures had been abolished in the UK and the US, in many continental European countries married women still had very few rights. For instance in France, married women received the right to work without their husband's permission in 1965. Feminists also worked to abolish the marital exemption in rape laws which precluded the prosecution of husbands for the rape of their wives.

The birth of feminism in Europe finally inspired literary critics to apply the spirit of feminism on literary analysis. In the beginning, feminism was a social theory which was adapted to literature. There are no differences between feminism as social theory and the theory of literary work analysis because both focus on gender equality. The birth of feminism analysis on literature is the contribution of genetic structuralism. Taine cited by Endraswara (2008) states that literary work is not only an imaginative fact but also a recording of culture and social situation when it is written.

Explicitly, genetic structuralism emphasizes the necessity of literary work which is seen as a copy of the situation and the condition of society when the work was written. This means that the researchers get an inspiration from the dynamics of community life and it is not pure imagination. So the genetic structuralism seeks to provide more to the external analysis of the literary works. Dealing with this view, genetic structuralism criticizes and gives new offer to literary review theory that was born earlier. It is pure structuralism which only emphasizes the intrinsic side.

Thus, the birth of feminism that tries to look at and examine the literature from the perspective of women's oppression is part of the development of the analysis of genetic structuralism. Feminists believe that literature was not born in a social void.

\section{E. The theories of feminism}

There are four main types of feminist theory that attempt to explain the societal differences between men and women. First is gender difference. Gender difference perspective examines how women's location in, and 
experience of, social situations differ from men's. Feminist theorists believe that the different roles assigned to women and men within institutions better explain gender difference, including the sexual division of labor in the household. Existential and phenomenological feminists focus on how women have been marginalized and denied the opportunity for self-realization (Freedman, 2001).

Second is gender-inequality. This theory recognizes that women have been isolated to the private sphere of the household and, thus, left without a voice in the public sphere (Freedman, 2001). Bouchier as cited by Jones (2010) states that family is a basic institution which exploits women. Further, Fakih (2012) argues that women are still expected to manage the private sphere and take care of household duties and child rearing making new discrimination to women for it increase women's work burden.

Third is gender oppression. According to Barker (2003) oppression is the social act of placing severe restrictions on an individual, group or institution. While Deuthsch (2006) explains that oppression is the experience of repeated, widespread, systemic injustice. With regards to the two above concepts, the theory of gender oppression argues that not only are women different from or unequal to men, but they are actively oppressed, subordinated, and even abused by men. To comprehend the above theory of gender oppression, psychoanalytic feminism such as the psychology Freud's view of feminism (Ahmed, 2012) and radical feminism are discussed. Psychoanalytic feminists attempt to explain power relations between men and women by reformulating Freud's theories of the subconscious and unconscious, human emotions, and childhood development. While radical feminists argue that being a woman is a positive thing in and of itself but that this is not acknowledged in patriarchal societies where women are oppressed. They identify physical violence as being at the base of patriarchy, but they think that patriarchy can be defeated if women recognize their own value and strength, establish a sisterhood of trust with other women, confront oppression critically, and form female separatist networks in the private and public spheres. Radical feminism is the breeding ground for many of the ideas arising from feminism. Radical feminism attempts to draw lines between biologically determined behavior and culturallydetermined behavior in order to be free both men and women as much as possible from their previous narrow gender roles.

Fourth is structural oppression. This theory posits that women's oppression and inequality are a result of capitalism, patriarchy, and racism. It 
seeks to explain oppression and inequality across a variety of variables, including class, gender, race, ethnicity, and age. It may be said that not all women experience oppression in the same way. They face different forms of discrimination in the workplace.

\section{METHODOLOGY}

This study used descriptive qualitative research method. To describe women resistance toward discriminations, feminism approach was applied. The source of the data was the second edition of Bekisar Merah novel written by Ahmad Tohari. The novel was published by PT Gramedia Pustaka Utama in January of 2013. The data were in the form of words, phrases, sentences, and paragraphs on Bekisar Merah which portray women's discrimination toward Lasi, the women figure in the novel, and power types formulated by her when resisting discrimination. The data collected was based on some steps; (a) formulating key words or phrases pertinent to the problem or question of interest,(b) searching the general references for relevant primary sources, (c) obtaining and reading relevant primary sources, and noting and summarizing key (Onwuegbuzi, Leech, \& Collins, 2012). This is then followed by (d) the researcher reading Bekisar Merah novel written by Ahmad Tohari, (e) marking the data which by the researcher as corpus, and (f) categorizing the data based on the problem focus of the study. In analyzing the data in this study, content analysis was applied. It was used to determine the presence of certain words or concepts within texts or sets of texts. Content analysis was applied in this study to find out the content and meaning of the text. To comprehend the sense of the text, an analytical construct was applied. Researchers quantified and analyzed the presence, meanings and relationships of such words and concepts, then make inferences about the messages within the texts. Content analysis which was applied in this study was through inductive approach. Elo and Kyngas (2007) divided the steps of inductive approach into open coding, creating categories, and abstraction. Thus, in this research, open coding was done by writing notes and headings in the text while reading, then listing categories that are grouped under higher order headings. The aim of grouping the data was to reduce the number of categories by collapsing those that are similar or dissimilar into broader higher order categories. The last is abstraction. It means formulating a general description of the research topic through generating categories. To get trustworthiness of the data, three triangulations were conducted: (1) theoretical triangulation was used to 
confirm more than one theoretical position in interpreting data, (2) methodological triangulation was used to apply more than one method for gathering data, meanwhile (3) investigator triangulation was conducted to compare between researchers in the field and interpret compiled data.

\section{RESULTS AND DISCUSSION}

The discriminations against women which were manifested in the Bekisar Merah novel can be seen as the following data. There were eight women discriminations and three kinds of women resistance toward discriminations.

\section{A. Woman discriminations}

(1) Domestic abuse

Domestic abuse, also known as spousal abuse, occurs when a man in an intimate relationship or marriage tries to dominate and control their wife. Domestic abuse that includes physical violence is called domestic violence. Domestic violence and abuse are used for one purpose: to gain and maintain total control over the victims. Domestic abuse toward Lasi in Bekisar Merah novel can be seen as follows:

Malah perangai Darsa sekarang berubah. Ia jadi suka marah, sepanjang hari uring-uringan. Kemarin Darsa membanting piring hanya karena Lasi agak lama pergi ke warung. Aku kasihan kepada Lasi. Suami seperti kambing lumpuh, pakaianya yang sengak harus dicuci tiap hari, tapi saban kali Lasi malah kena marah ('Darsa's character has a lot of changes. He is easy to be angry now. Yesterday, he broke the plate because Lasi took a long time to go to a food stall. I pity her. Her husband was like a lame goat whose dirty clothes should be washed every day, but she was always to be an object of her husband's temperament) (Tohari, 2013, p. 44).

The above quotation demonstrates how Darsa treated his wife in a very rude way whereas the instigation was really simple. Lasi was taking too much time going to the food stall. It showed that Darsa who felt himself superior tried to dominate his wife, and he used his being angry to order his wife around. He wants Lasi to obey him quickly without considering any of his wife's condition. Lasi, as his wife, must accept that unpleasant treatment although she gives fair treatment toward her husband every day while doing some domestic work. As 
explained by Freire (2013), the relation between child and parents commonly indicates the rule of culture practiced in society. With regards to his opinion, the above data illustrated how patriarchal culture was practiced in Lasi's family. The fundamental understanding gave Lasi the understanding that men have control to all parts of life including within the family. Thus, as a woman, Lasi, had to follow what was instructed by her husband. The right to create a decision in the household was totally held by man.

\section{(2) Molestation}

Molestation is a sexual abuse which is in the form of holding or touching the female's body without their acceptance (Fakih, 2012). This form can be observed from the quotation of data below.

Lasi hamper tertidur. Namun terkejut karena tiba-tiba lampu padam dan ada bioskop di tembok depan sana. Lasi kembali terjaga. Apalagi kemudian Handarbeni kembali duduk disampingnya sambil melingkarkan tangan ke pundaknya (Lasi almost slept, but she was shocked because the lamp suddenly went out and there was a motion picture in wall. She was not sleepy anymore due to the fact that Handarbeni sat close to her as he put his hand on her solders) (Tohari, 2013, p. 161).

In the situation above, it must be noted that, when a woman, like Lasi, does not resist an unwanted sexual advance, it does not mean that she gives her consent. Sometimes physically resisting can put a victim at a bigger risk for further physical or sexual violence. The point of this is truly related to Handarbeni's form of sexual abuse towards Lasi. Without asking Lasi, he puts his hand on her shoulders. Lasi who cannot do anything just let herself to be touched by him.

\section{(3) Gender Harassment}

Gender harassment means statements and behaviour that is degrading someone (women) based on her sex. Gender harassment in the novel was manifested in the data citations below.

Lasi menahan napas. Tetapi di sebelahnya Handarbeni malah tertawa ngikik. Handarbeni sudah belasan kali melihat film cabul yang sedang diputarnya itu dan kini sengaja menyajikannya kepada Lasi demi sebuah tujuan. Dan lasi kembali menahan napas ketika melihat si lelaki purba mulai memaksa perempuan pasangannya. Brutal seperti kambing jantan 
(Lasi held her breath, but Handarbeni who was beside her laughed loudly. Handarbeni had seen that obscene movie a dozen times which was being played and he deliberately presented it to Lasi for a certain purpose. Lasi held her breath for the second time when she saw the ancient man began enforcing woman partner. Brutal is as a goat) (Tohari, 2013, p. 162).

In the above quotation, both Handarbeni and Lasi were in a private room where Handarbeni tried to invite Lasi to be in an intimate situation. The way to persuade Lasi was not verbally, but by showing an obscene video. Handarbeni had a purpose to raise Lasi's desire. In contrary with his purpose, Lasi felt uncomnvertable. In this case, there was a gender harassment done by Handarbeni. As explained before, showing obscene picture or video for the certain purpose was categorized as part of woman discrimination.

\section{(4) Seduction Behavior}

Seduction behavior was indicated by the presence of requests that were obscene or derogatory behavior based on sexual nature without the existence of a threat. Notice the following data.

Bambung hanya tersenyum dengan sedikit mengangkat alis. Dengan cara itu sesungguhnya Bambung ingin mengatakan. Biasa, apalah yang dikehendaki lelaki ketika sedang berdua dengan perempuan di sebuah ruangan yang sangat pribadi (Bambung just smiled with slightly raised eye brows. In that way, Bambung actually wanted to say if there was no other thing that he wished from a woman which was in a very private room unless an intimate service). Tohari, $2013 \mathrm{p}$. 267).

The above citation showed that Mr. Bambung attempted to seduce Lasi to have intercourse with him. Indeed, it was not done verbally, but by showing his behavior or body language to convey his desire to Lasi.

\section{(5) Imposition}

The imposition as illustrated in that novel was sexual intimidation which was done roughly or overtly. This kind was manifested in the quotation below.

Bambung yang merasa dirinya Rusman, bangkit. Dia siap mulai gerakan tari Gatot kaca Gandrung. Gerakannya boleh juga. Dan sepenggal nyanyian asmara mulai terdengar dalam nada takkaruan: Wisma 
nutadhuh wong ayu... Dengan gerakan bagai Rusman yang sebenarnya Bambung merengkuh dan membopong Lasi.Bekisar merah itu tak sempat menolak.Maka tubuhnya terangkat dan terayun-ayun dalam dekapan Bambung. (Bambung who feels himself as Rusman rises. He was ready to start a dance of "Ghatotkaca". He danced well enough and a piece of romance began to besung: Please pretty girl just follow what I want... With a movement which was like Rusman, Bambung embraced and carried Lasi. She cannot refuse then her body was lifted and swung in his embrace) (Tohari, -2013, p. 271).

The above data showed the harsh and brash treatment of Mr. Bambung toward Lasi. He tried to force Lasi to engage in something which she did not want. Even when Mr. Bambung did not get a response, he immediately held Lasi who was powerless against a man who was so respected in the elite level politicians of the country.

(6) Coercion

The coercion is typified by the action such as invitation to have intercourse with threat from the abuser. The example of data can be seen as follows.

Ayo, Las. Kamu telah membuat Pak Bambung benar-benar marah. Sekarang kamu harus ikut kami pulang ke Jakarta. Kalau kamu menurut, kami berjanji akan memperlakukan kamu seperti biasa. Namun bila kamu banyak tingkah, tak tahulah. Yang jelas Pak Brangas pasti sudah menyiapkan borgol buat kamu. (Come on Las. You had made Mr. Bambung really angry. Now, you must come with us to return to Jakarta. If you cooperate, we promise to treat you as usual. But if you don't, I do not know what will happen. Indeed, Mr. Brangas must have prepared handcuffs for you) (Tohari, 2013, p.316).

From the above quotation, we can see how the threat was given to Lasi. In the first time, Lasi did not want to go back to Mr. Bambung's house. Finally, Mrs. Lanting, a woman who sent her to Mr. Bambung, said to her if she stand with her decision she will be just like a law breaker who should be taken to prison with a handcuff on her hand. Treating Lasi just like a law breaker is classified by the researchers as a threat for her. 
(7) Bribery

The bribery is an invitation to do things pertaining to sexual attention accompanied with a promise to get certain benefits such as gifts, salary increases, or job title.

Bila menurut nanti kamu bisa minta apa saja atau ingin jadi apa saja. Apa kamu ingin jadi... komisaris bank? Atau anggota parlement? Ya, mengapa tidak? Kalau mau, nanti saya yang akan ngatur, maka semuanya pasti beres (If you follow what I want you ask for anything or to be anything. Do you want to be the commissioner of banks or member of a parliament? Why not? If you want to, I can organize everything, and everything will be like you want it to be). (Tohari, 2013, p. 272).

The data revealed how Mr. Bambung who had great power in the government offered to Lasi to have a respectable career in a bank or to be a member of parliament. It was done in order to persuade Lasi to have a close relation with him. As explained in the previous paragraph, the promise was not only in the form of money but also in everything which can make the woman to make a deal with a man. In this context, Mr. Bambung used his high position such as explained above, to get what he wants.

\section{Subordination}

The term 'women's subordination' refers to the inferior position of women, their lack of access to resources and decision making, and to the patriarchal domination that women are subjected to in most societies (Sultana, 2010). The data can be seen below.

Oalah, Las, dasar kamu perempuan dusun. Kamu tidak tahu bahwa kamu punya sesuatu yang disukai setiap lelaki: wajah cantik dan tubuh yang bagus. Kamu juga mungkin tidak tahu bahwa sesunggunya lelaki kurang tertarik, atau malah segan terhadap perempuan yang terlalu cerdas apalagi perpendidikan terlalu tinggi. Bagi lelaki, perempuan yang kurang pendidikan dan miskin tidak jadi soal asal dia cantik. Apa lagi bila si cantik itu penurut. (my goodness, Las, you were truly still a hick. You did not know that you had something which were interested every man: a pretty face and nice body. You also might not know that men were less interested or even reluctant to women who were too smart especially having high level of education. For men, women 
were lack of education and poor were not matter as long as she was gorgeous. (Tohari, 2013, p. 144).

The above data was a dialogue between Lasi and Mrs. Lanting who made Lasi as a merchandise. She tried to indoctrinate Lasi with the idea that a woman's value lies in their physical beauty and not the quality or capacity of the individual as a human being. Moreover, she should behave much less tractable that obviously legitimized women to be under the control of men.

The understanding of patriarchy culture that women have a faint nature and irrational are deemed inappropriate to serve as a leader. So far, the feminism movement that emerges to oppose the notion arguably successful because we see a lot of women who already take part in the political world. But unfortunately it is still symbolically and not substantively. That means if the spirit of feminism is not understood and applied correctly.

As illustrated in the above data, it showed that although female had chance to be such kind of a member of parliament, it did not mean that if they had the same opportunities as men to vote the idea. It proved that the discrimination of women did not go away with the seating of a woman in a political institution.

\section{(9) Women resistance toward discriminations}

In disclosing the resistance formulated by women figure in Bekisar Merah novel, the researchers observed the way of thinking, attitudes, and actions of the main character against discriminatory treatment that she received as a consequence of men's domination. Some forms of the resistance are physically, mentally, and verbally.

(a) Physical resistance

Physical resistance was Lasi's action to fight all forms of discriminatory treatment which she received. This form was contained in the excerpt below.

Lasi mencabut kayu penggaris dari ketiaknya, lari menyebrang titian dan siap melampiaskan kemarahan kepada para penggoda. (Lasi revoked the ruler from her armpit, run cross the footbridge, and ready to vent her anger to the tease') (Tohari, 2013, p. 26).

The above data was a piece of events in the Bekisar Merah novel. It described the situation when she and some friends were on the way home from school. 
In that quote, Tohari did not use figure of speech. He directly showed the physical resistance was made by Lasi. It was reflected from a ruler used by Lasi to fight her male friends who continued to mock her as a child of rape. Regardless of the physical nature as a woman, she ventured to oppose the mistreatment against her.

(b) Mental resistance

Mental resistance was Lasi's way of thinking. It often occurred because women were not strong enough to against it physically due to the domination and control exercised by men so strong and sometimes physical resistance even more threatening women. Some excerpts from the novel that described this model are as follows.

Kedua tangan Lasi mengepal. Lasi terlempar kembali ke dalam dunia hayal, menjadi kepiting batu raksasa dengan capit dari gunting baja. Lasi siap pertama-tama memangkas putus leher Bunek, kemudian leher Darsa, kemudian leher semua orang. (Lasi's hands clenched. She was in an imagination of being a giant stone crab with claws of steel scissors. Lasi was ready to cut Bunek's neck, Darsa's neck, and then everyone else) (Tohari, 2013, p. 55).

The above data was a condition after Darsa, Lasi's husband, was dishonest to have a special relation with another woman. Different from what was previous mentioned before; the above quote reflected the use of figure of speech which was in form of a simile. Tohari supposed Lasi with a giant stonecrab with claws of steel scissors to discard all forms of unfair treatment that she received from her husband and all the people around her. Because it is presented an internal conflict, it was classified into the mental struggle of the character.

\section{(c) Verbal Resistance}

What the researchers meant by this model was a statement of Lasi to resist, oppose against all the unfair treatment that she received. Although merely verbal, the researchers found a commitment and effort of the main character not to continue to let her being subjected by male. The form can be found in the quote below.

“Tidak!"Lasi bereaksi cepat. Namun sanggahannya itu diucapkan secara tenang dan dengan penuh rasa percaya diri. Bambung agak terkejut karena Lasi berani memotong ucapannya. ('No!Lasi reacted quickly, but that objection was spoken calmly and with full confidence. 
Bambung was surprised because Lasi dared to break him off. (Tohari, 2013, p. 330).

The above quotation was a fragment of an event when Bambung got Lasi to abort. The content was the result of her marriage to Kanjat. Lasi rejected the desire of Bambung by saying "no" firmly. Here, we saw that Lasi no longer allowed was under Bambung's superiority. However, she fought for the rights of herself by cutting the words of Bambung. The text used by Tohari was unadorned or directly to the point without any deviation of meaning.

\section{CONCLUSION}

The result of the study showed eight forms of discriminations and three forms of women resistances. The discriminations were domestic abuse, molestation, gender harassment, seduction behavior, imposition, coercion, bribery, and subordination. The resistances were physically, mentally, and verbally. The researchers found the discrimination for women with not having a chance to voice their idea which becomes the substantive of the political chance. The gender inequalities caused by patriarchy culture becomes worst for they are harassed while being subordinated. From the result of the analysis, the researcher also discovered certain ways for women to resist those discriminations.

\section{REFERENCES}

Ahmed, S. (2012). Sigmund Freud's psychoanalytic theory Oedipus complex: A critical study with reference to D. H. Lawrence's "Sons and Lovers". Internal Journal of English and Literature, 3 (3) Retrieved October14, 2015 from http://www. academicjournals.org/ijel DOI: 10.5897/IJEL11.137.

Ambarwati, A. (2009) Perspektif Feminis Dalam Novel Perempuan Di Titik Nol Terjemah Novel Imraâ $]^{\mathrm{TM}}$ Atunâ $\mathrm{IT}^{\mathrm{TM}}$ Inda Nuqtah Al- Shifr Karya Nawal El-SaẫTM Dawi Dan Perempuan Berkalung Sorban Karya Abidah El-Khalieqy. Jurnal Muwazah, 1, (1).

Barker, R. L. (2003). The Social Work Dictionary, 5th ed. Washington, DC: NASW Press. 
Bhasin \& Khan. (1995). Persoalan Pokok Mengenai Feminisme dan Relevansinya. Jakarta: Gramedia Pustaka Utama.

Butler, J. (1990). Gender Trouble: Feminism and the Subversion of Identity. New York and London: Routledge.

Cameron, D. (2010). Cultural Strategy. Oxford: Oxford University Press.

Deutsch, M. (2006). A framework for thinking about oppression and its change. Social Justice Research. 19 (1).

Elo, S. \& Kyngas, H. 2007. The qualitative content analysis process .Journal of Advanced Nursing. Retrieved September 4, 2015 from (http://academic. csuohio.edu/kneuendorf/c63309/Articles-

FromClassMembers/Amy.pdf.

Endraswara, S. (2008). Metodologi Penelitian Sastra: Epistemologi, Model, Teori, dan Aplikasi. Yogyakarta: PT. Buku Kita.

Fakih, M. (2012). Analisis Gender dan Transformasi Sosial. Yogyakarta: Pustaka Pelajar.

Freire, P. (2013). Pendidikan Kaum Tertindas, translated by LP3ES Redaction. Jakarta: LP3ES.

Freedman, J. (2001). Feminism. Buckingham: Open University Press.

Gay, R. (2012). Bad feminist. Virginia Quarterly Review, 88 (4).

Herlambang, W. (2013). Kekerasan Budaya Pasca 1965: Bagaimana Orde Baru Melegitimasi Anti-Komunis memelalui Sastra dan Filem. Yogyakarta: Marjin Kiri.

Jones, P. (2010). Pengantar Teori-Teori Sosial dari Teori Fungsionalisme Hingga Postmodernisme. Translated by Ahmad Fedyani Saifuddin. Jakarta: Yayasan Pustaka Obor Indonesia.

Krolokke, C \& Sorensen, A. S. (2005). Three waves of feminism: from suffragettes to girls. Gender Communication Theories and Analyses: From Silence to Performance. Troutdale: New Sage Press.

Kuncoro, B. P. (2010). Membaca diskursus post-feminisme melalui novel perempuan di titik nol. Jurnal Komunitas, 2 (2). 
Kurnia, L. A. EF Priyadi, W.A. (2013). Kajian feminisme dalam novel secuil hati wanita di teluk eden karya Vanny Chrisma W. Jurnal Pendidikan dan Pembelajaran, 2 (7).

Luken, Rebecca.J. (2003). A Critical Handbook of Children's Literature. Boston: Pearson Education, Inc.

Money, J. (1988) Gay, Straight, and In-Between: The Sexology of Erotic Orientation. New York: Oxford University Press.

Onwuegbuzie. A. J., Leech, N. L., \&. Collins, K.M. T. (2012). The Qualitative Report 17, (56), pp. 1-28. Retrieved September 4, 2015 from http://www. nova.edu/ssss/QR/QR17/ onwuegbuzie.

Rudman, L. A. \& Glick, P. (2008).The Social Psychology of Gender: How Power and Intimacy Shape Gender Relations: Texts in Social Psychology. New York and London: The Guildord Press.

Sugihastuti \& Sastriyani, S. H. (2007). Glosarium Seks dan Gender. Yogyakarta: Carasvati Books.

Sultana. A. (2010). Patriarchy and women's subordination: a theoretical analysis. Arts Faculty Journal 4, July. Retrieved October 16, 2015 from http://banglajol.info/ index.php/AFJ/article/view/12929.

Tohari, A. (2013). Bekisar Merah. Jakarta: PT Gramedia PustakaUtama.

Umar, N. (2005). Tafsir Sosial: Mendialogkan Teks Dengan Konteks. Yogyakarta: Elsaq Pres.

West, C. \& Zimmerman, D. (1987). Doing Gender: Gender and Society. New York and London: Routledge.

Windiyati, D. (2008). Pemberontakan perempuan bali terhadap diskriminasi kelas dan gender: kajian feminis novel tarian bumi karya Oka Rusmini. Journal Humaniora, 20 (3). Retrieved October 9, 2015 from http://journal. ugm.ac.id/jurnalhumaniora/article-/view/945/792. 